\title{
ÚNG DỤNG MÔ HÌNH MIKE MÔ PHỎNG NGẬP LỤT DO XẢ LŨ KHẨN CẤP VÀ VỠ ĐẬP ĐỊNH BÌNH
}

\author{
Bùi Văn Chanh ${ }^{1}$, Nguyễn Văn Lý ${ }^{1}$
}

Tóm tắt: Hồ Định Bình là hồ chứa nước lớn nhất tỉnh Bình Định, quá trình vận hành điều tiết hồ ảnh huởng rất lớn đến diễn biến ngập lụt hạ lưu sông Kôn - Hà Thanh. Trong nhũng năm gần đây, nhũng trận lũ lớn xuất hiện trên sông Kôn - Hà Thanh ngày càng nhiều, thời gian kéo dài nên việc vận hành hồ Định Bình đảm bảo an toàn đập và giảm thiểu ngập lụt hạ du là rất cần thiết.Khi lũlớn về hồ Định Bình, việc vận hành vìa đảm bảo an toàn vìa giảm thiểu ngập lụt ha du là rất khó khăn do hồ hông có dung tích phòng lũ và thường phải xả lũ khẩn cấp. Việc xả lũ khẩn cấp sẽ gây ra ngập lụt sâu hơn, đặc biệt là vỡ đập không chỉ gây ra ngập lụt sâu hơn nhiều mà còn xuất hiện dòng chảy lớn. Do đó, nghiên cứu xây dưng bản đồ ngập lưt cho các tình huống vỡ đập, xả lũ khẩn cấp phuc vu công tác cảnh báo ngập, rủi ro nhằm hạn chế thiệt hại tác động tiêu cực của hồ chứa, trong đó có hồ Định Bình là rất cần thiết.

Từ khóa: Ngập lụt, lưu vục sông Kôn - Hà Thanh, hồ Định Bình.

Ban Biên tập nhận bài: 08/02/2019 Ngày phản biện xong: 15/03/2019 Ngày đăng bài: 25/04/2019

\section{Mở đầu}

Sông Kôn - Hà Thanh là con sông lớn nhất tỉnh Bình Định, hạ lưu có điều kiện kinh tế xã hội phát triển, trong đó có thành phố Quy Nhơn, thị xã An Nhơn, thị trấn Diêu Trì. Trong những năm gần đây đã xảy ra nhiều trận lũ lớn, thời gian kéo dài, các trận lũ liên tiếp dồn dập gây thiệt hại nghiêm trọng cho các địa phương. Diễn biễn ngập lụt vùng hạ lưu khá phức tạp do tổ hợp lũ của sông Kôn và sông Hà Thanh, cửa ra gồm nhiều nhánh nhỏ đổ vào đầm Thị Nại và có nhiều đê bao, đường giao thông phức tạp. Diễn biễn ngập lụt hạ lưu sông Kôn - Hà Thanh lại càng phức tạp và nguy hiểm hơn khi có sự điều tiết của các hồ chứa. Do có nhiều hồ chứa nước thủy lợi và thủy điện trên lưu vực, Thủ tướng Chính phủ đã ban hành Quy trình vận hành liên hồ chứa lưu vực sông Kôn - Hà Thanh. Trong các hồ chứa trên lưu vực này, hồ Định Bình có tác động chủ yếu. Với dung tích toàn bộ là 226,21 triệu $\mathrm{m} 3$, vận hành của hồ Định Bình đã chi phối toàn bộ diễn biến ngập lụt hạ lưu sông Kôn - Hà Thanh. Do đó trong bài báo này chỉ đề cập quá ${ }^{1}$ Đài Khí trợng Thủy văn khu vục Nam Trung Bộ Email: buivanchanh@gmail.com trình xả lũ khẩn cấp và vỡ đập Định Bình đến diễn biến ngập lụt hạ lưu sông Kôn - Hà Thanh.

Phạm vi nghiên cứu là hạ lưu sông Kôn - Hà Thanh; trên sông Kôn từ chân đập Định Bình đến đầm Thị Nại; trên sông Hà Thanh từ cầu Diêu Trì đến cửa biển Quy Nhơn. Vùng ngập bao gồm toàn bộ huyện Tuy Phước, An Nhơn, phía bắc thành phố Quy Nhơn, phía nam huyện Phù Cát, phía đông nam huyện Tây Sơn. Từ phạm vi nghiên cứu xác định được các xã cần thu thập bản đồ địa hình tỷ lệ 1/10.000, mặt cắt, vết lũ và số liệu khí tượng thủy văn.

\section{Phương pháp nghiên cứu}

* Mô hình Mike 11

Mô hình thủy lực 1 chiều được thiết lập cho mạng lưới sông Kôn - Hà Thanh, công trình, mặt cắt ngang, các thông số thủy lực và các biên đầu vào. Biên lưu lượng tại chân đập Định Bình, cầu Phú Phong và cầu Diêu Trì. Biên mực nước là mực nước triều tại trạm hải văn Quy Nhơn, vị trí các biên gồm 6 nhánh sông đổ vào đầm Thị Nại.Mạng lưới sông được số hóa bằng phần mềm MapInfo 15.0 trên nền bản đồ địa hình tỷ lệ 1/10.000 hệ tọa độ VN2000 để nhập vào mô hình Mike 11 (Hình 1). Mặt cắt trên sông Kôn có 28 
mặt cắt, sông Hà Thanh có 9 mặt cắt [1]. Đối với lưu vực sông Kôn - Hà Thanh, hệ số nhám được tra trong bảng tra hệ số nhám manning của M.F.Xripnut cho lòng sông tự nhiên và bảng tra Paverlopxki cho lòng dẫn nhân tạo. Hệ số nhám ban đầu của các sông được lấy bằng 0,035 cho lòng sông và 0,039 cho bờ sông tự nhiên, các hệ số này được thay đổi sau khi hiệu chỉnh mô hình.
Từ hệ số nhám ban đầu lấy trong bảng tra là 0,035, sau khi hiệu chỉnh hệ số nhám tối ưu nhất của bờ là 0,036 , của đáy là 0,033 . Mức độ phù hợp giữa các kết quả tính toán và thực đo được đánh giá theo tiêu chuẩn của $\mathrm{WMO}$, bằng chỉ tiêu Nash. Kết quả tại bảng 1 và các hình $2 \mathrm{a}, 2 \mathrm{~b}$, $2 \mathrm{c}$ dưới đây.

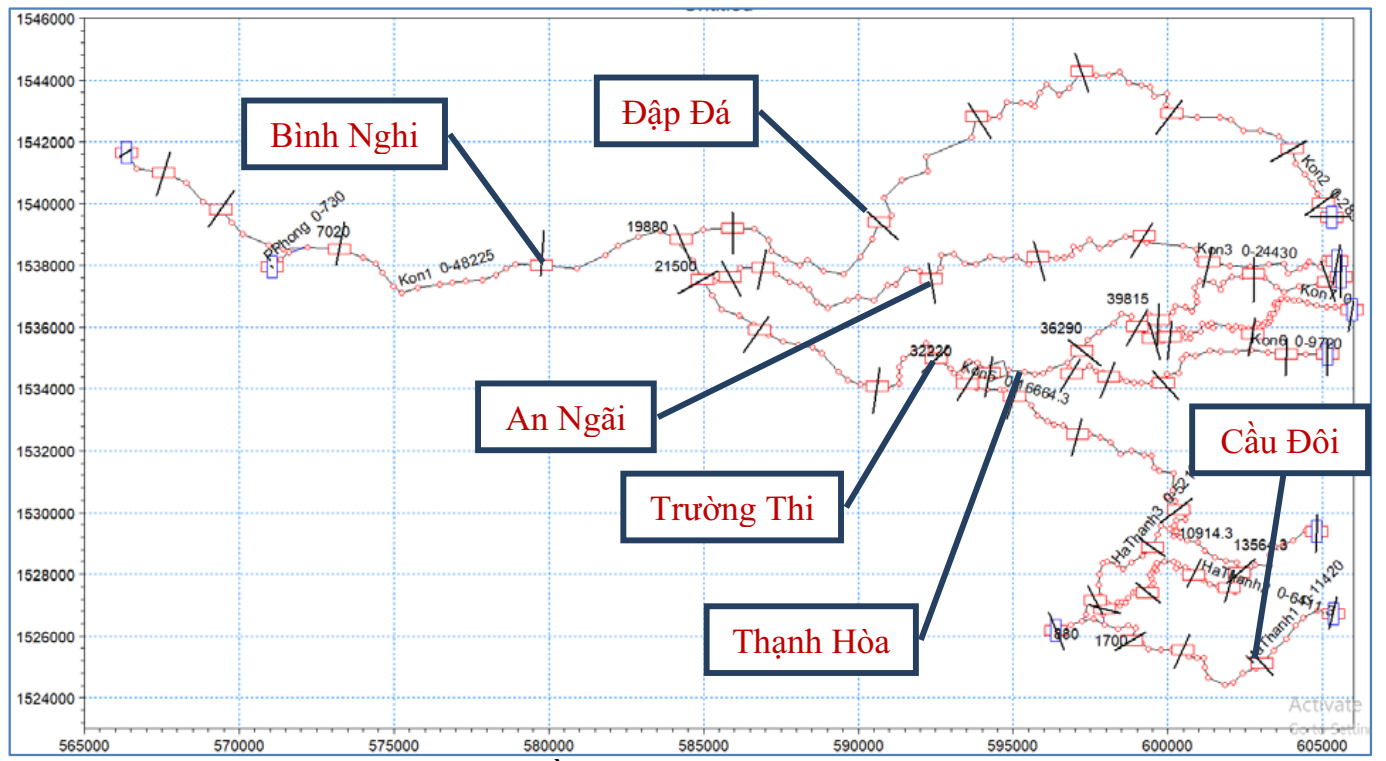

Hình 1. So đồ thủy lục mạng lưới sông [3]
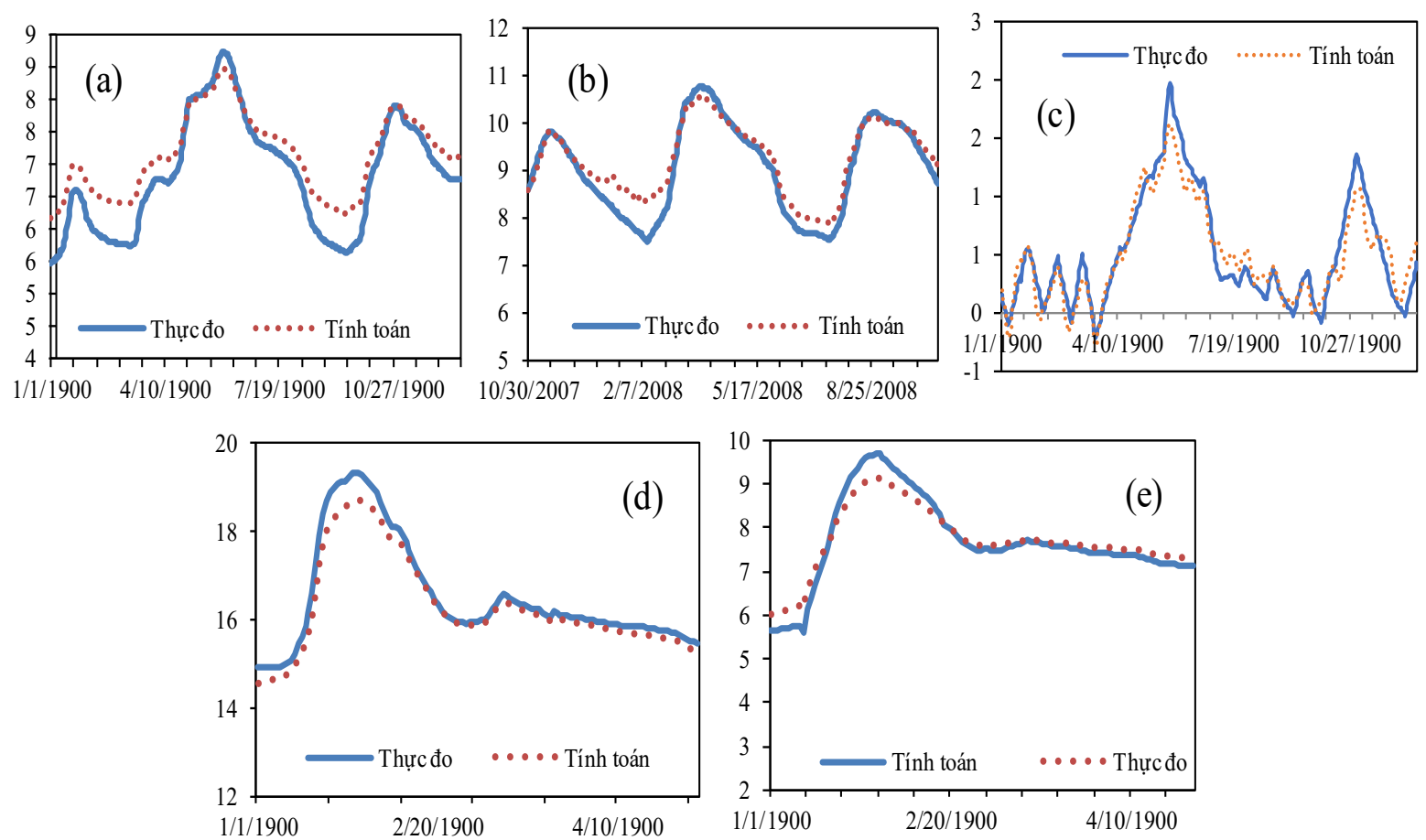

Hình 2. Kết quả hiệu chỉnh mô hình tại các trạm: (a) Thạnh Hòa; (b) Đập Đá; (c) Cầu Đôi; Kết quả kiểm định tại 02 trạm thủy văn: (d) Bình Nghi; (e) Thạnh Hòa [3] 


\section{BÀI BÁO KHOA HỌC}

Bảng 1. Đánh giá hiệu chỉnh mô hình Mike 11 bằng chi tiêu Nash (\%) [3]

\begin{tabular}{cccccc}
\hline $\begin{array}{c}\text { Mục } \\
\text { tiêu }\end{array}$ & $\begin{array}{c}\text { Trường } \\
\text { Thi }\end{array}$ & $\begin{array}{c}\text { Đập } \\
\text { Đá }\end{array}$ & $\begin{array}{c}\text { An } \\
\text { Ngãi }\end{array}$ & $\begin{array}{c}\text { Thạnh } \\
\text { Hòa }\end{array}$ & $\begin{array}{c}\text { Cầu } \\
\text { Đôi }\end{array}$ \\
\hline Hiệu & 88,2 & 88,3 & 80,3 & 78,5 & 89,3 \\
chỉnh & Tốt & Tốt & Khá & Khá & Tốt
\end{tabular}

Các trạm được sử dụng kiêm định bộ thông số là trạm thủy văn Bình Nghi và trạm Thạnh Hòa. Đánh giá bằng chỉ tiêu Nash: tại trạm Bình Nghi đạt 94,4\%, tại trạm Thạnh Hòa đạt 93,4\%. Theo tiêu chí của WMO, chất lượng mô phỏng đạt loại tốt (Hình 2d, 3e). Bộ thông số mô hình thuy lực một chiều đủ tin cậy để mô phỏng dòng chảy sông ngòi vùng hạ lưu sông Kôn - Hà Thanh [3].

* Mô hình Mike 21 [5]

Mô hình Mike 21FM được thiết lập trên cơ sở file địa hình, hệ số nhám và mưa gia nhập khu giữa. Dữ liệu địa hình được khai thác từ bản đồ địa hình tỷ lệ 1/10.000 hệ tọa độ VN2000 được
Bộ Tài Nguyên và Môi Trường xây dựng năm 2006 và cập nhật năm 2012. Lưới tính khu vực nghiên cứu hạ lưu sông Kôn - Hà Thanh được chia ở dạng lưới phi cấu trúc (Hình 3). Diện tích tam giác lớn nhất trong miền tính là $50.000 \mathrm{~m}^{2}$, đối với các công trình và lòng sông được chia lưới chi tiết hơn với diện tích tam giác lớn nhất là $5.000 \mathrm{~m}^{2}$, diện tích tam giác nhỏ nhất của miền tính là $26 \mathrm{~m}^{2}$. Hệ số nhám Manning vùng ngập $\mathrm{M}=32\left(\mathrm{~m}^{1 / 3} / \mathrm{s}\right)[3]$.

Số liệu hiệu chỉnh bộ thông số của mô hình Mike 21FM là dữ liệu vết lũ điều tra của trận lũ lớn nhất năm 2007. Bộ thông số hiệu chỉnh là hệ số nhám Manning trong mô hình Mike 21FM, các trị số ban đầu được xác định trong phần thiết lập mô hình Mike 21FM. Sau khi hiệu chỉnh hệ số nhám Manning vùng ngập $\mathrm{M}=30\left(\mathrm{~m}^{1 / 3} / \mathrm{s}\right)$. Kết quả hiệu chỉnh mô hình Mike 21FM với 125 vết lũ [1] được điều tra năm 2007 có sai số lớn nhất là $1,09 \mathrm{~m}$ và nhỏ nhất là $0,01 \mathrm{~m}$, sai số trung bình là $0,33 \mathrm{~m}$.

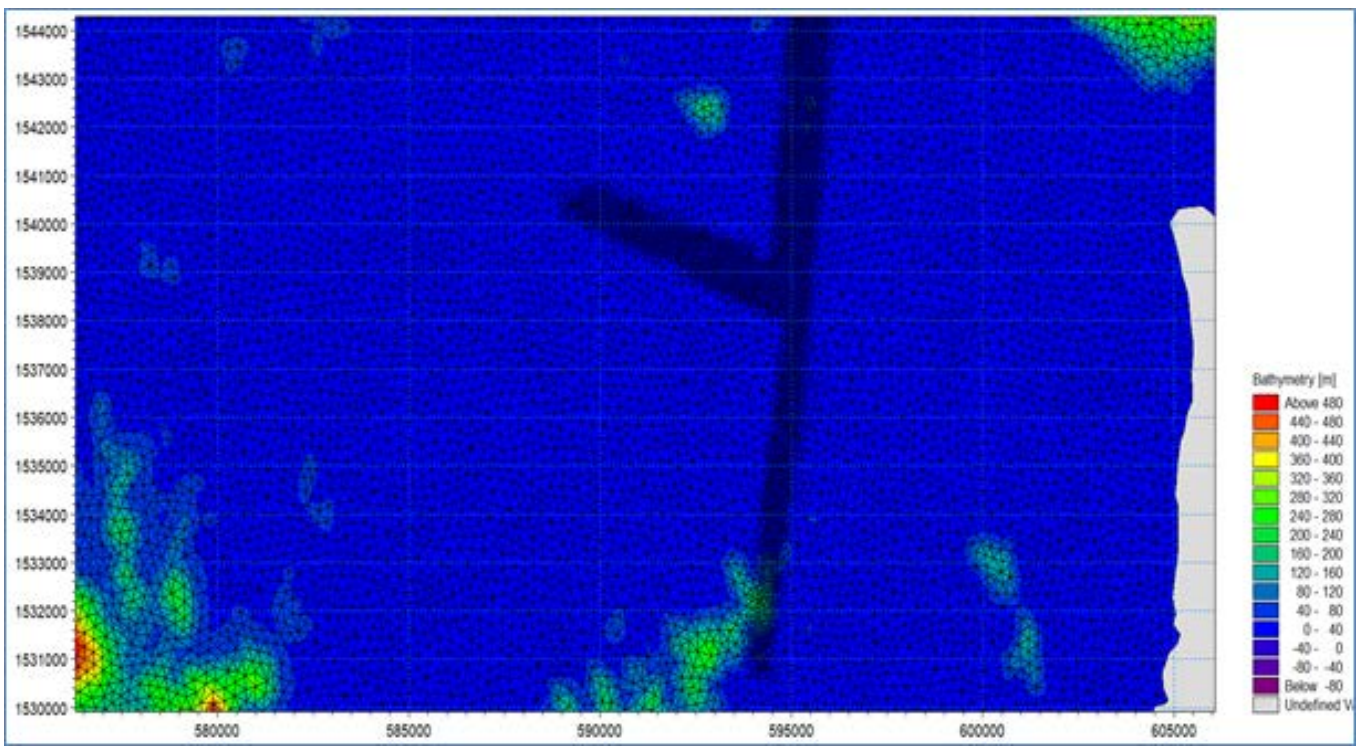

Hình 2. Vị trí hệ thống hồ mô phỏng trong so đồ mạng sông thuỷ lục 1 chiều

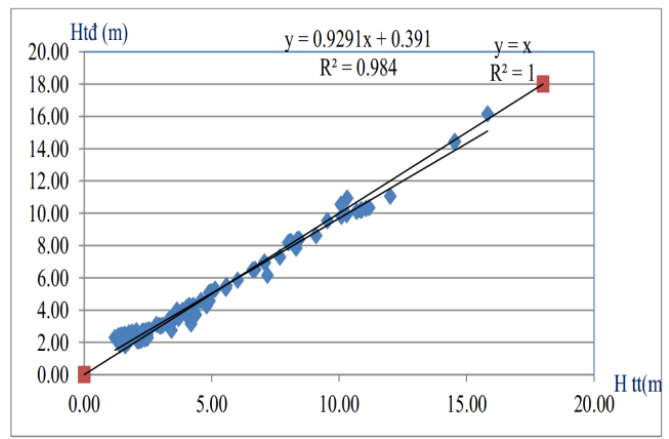

Hình 4. Quan hẹ mưc nước thực đo và tính toán tại các vết lũ năm 2007 [3]
Số liệu kiểm định bộ thông số của mô hình Mike 21FM là dữ liệu vết lũ điều tra của trận lũ lịch sử năm 2013, với 99 vết lũ [2] có sai số lớn nhất là $1,53 \mathrm{~m}$, điểm nhỏ nhất là $0,01 \mathrm{~m}$, trung bình là $0,30 \mathrm{~m}$. Kết quả hiệu chỉnh và kiểm định mô hình Mike 21FM đều cho hệ số tương quan giữa thực đo và tính toán tương đối tốt. Kết quả hiệu chỉnh có hệ số tương quan $\mathrm{R}=0,984$ (Hình 4), kiểm định có $\mathrm{R}=0,988$ (Hình 5). Vậy bộ 
thông số mô hình thủy lực 2 chiều đủ tin cậy để diễn toán mô phỏng ngập lụt cho vùng hạ lưu sông Kôn - Hà Thanh.

Hình 5. Quan hệ mưc nước thưc đo và tính toán tại các vết lũ năm 2013 [3]

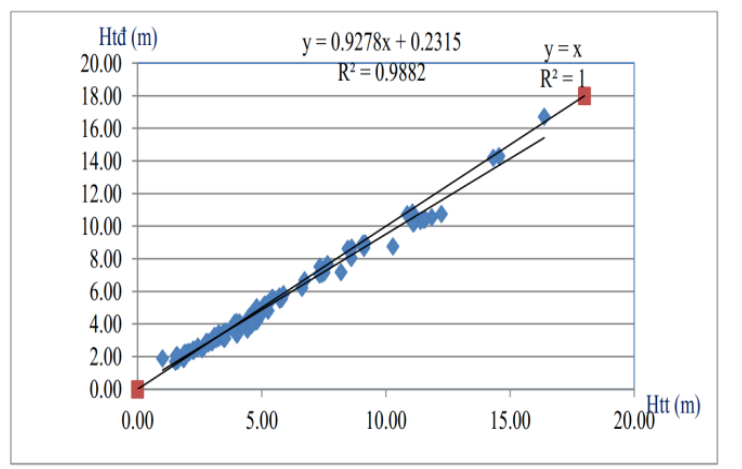

* Mô hình Mike Flood [6]

Mô hình Mike Flood được thiết lập trên cơ sở kết nối mô hình Mike 11 và Mike 21FM. Các nhánh sông trong mô hình Mike 11 được kết nối bờ phải và bờ trái với bản đồ địa hình trong Mike 21FM, kiểu liên kết này được xác định là kết nối nhánh (Hình 6). Các cầu cống trong Mike 11 được kết nối kiểu cấu trúc tiêu chuẩn phía thượng lưu và hạ lưu công trình với bản đồ địa hình trong Mike 21FM.

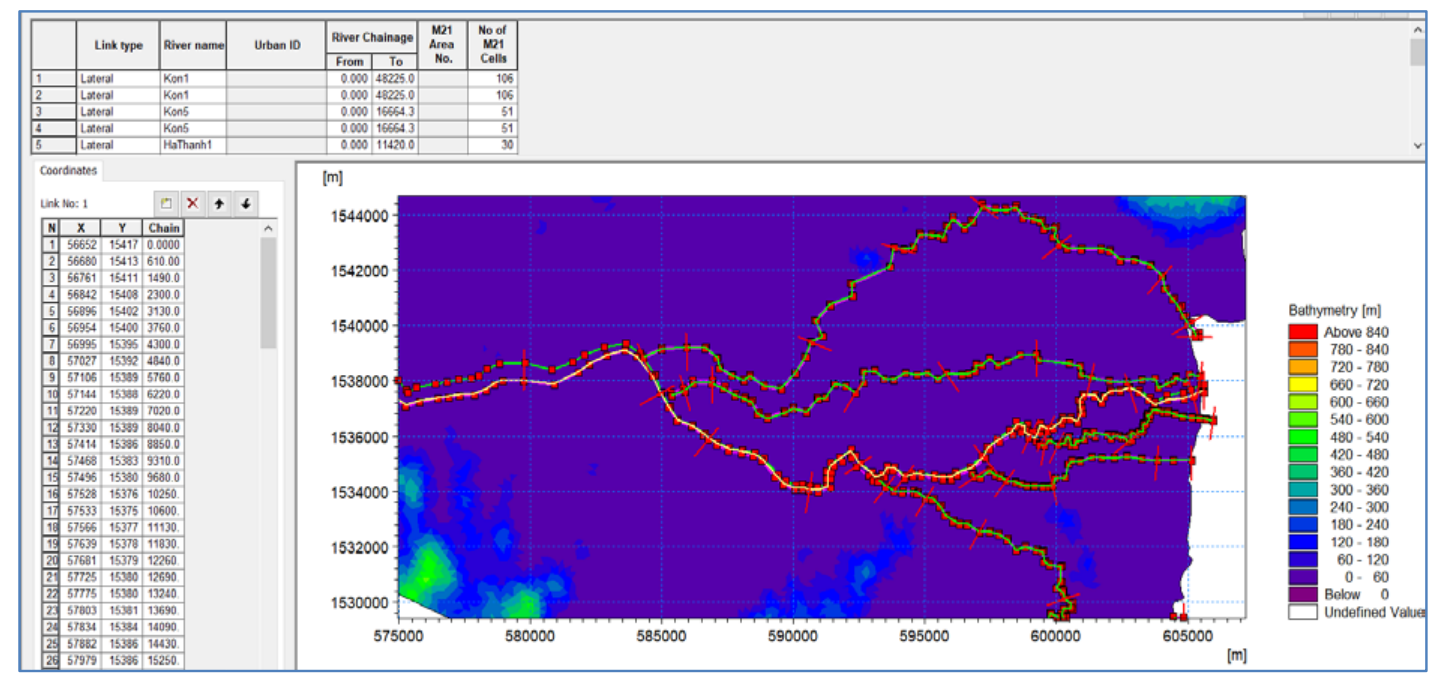

Hình 6. Kết nối Mike11 và Mike21[3]

\section{* Mô đun Sóng võ đập}

Để mô phỏng ngập lụt của các tình huống vỡ đập cần tính toán lưu lượng hạ du đập trong trường hợp đập Định Bình bị vỡ. Tình huống vỡ đập được tính toán với sự cố hồ chứa, lưu lượng lũ về hồ ứng với lũ thiết kế và lũ kiểm tra sau đó bị vỡ với mực nước dâng bình thường. Lũ thiết kế tương ứng với tần suất $0,1 \%$ và kiểm tra là
$0,02 \%$. Quá trình lưu lượng về hạ du đập gồm hai phần: xả lũ khẩn cấp và lưu lượng vỡ đập. Giải thiết vớ đập do thủng thân đập từ giữa và phát triển vết vỡ tuyến tính dạng hình thang.

Phương án vỡ đập được tính từ modun vỡ đập trong mô hình Mike 11 theo kịch bản vỡ đập bất lợi nhất. Công thức tính lưu lượng qua lỗ vỡ:

$$
\mathrm{Q}=\mathrm{C}_{\mathrm{v}} \mathrm{k}_{\mathrm{s}}\left(\mathrm{C}_{\mathrm{weir}} \mathrm{b} \sqrt{g\left(h-h_{b}\right)}\left(\mathrm{h}-\mathrm{h}_{\mathrm{b}}\right)+\mathrm{C}_{\text {slope }} \mathrm{S} \sqrt{g\left(h-h_{b}\right)}\left(h-h_{b}\right)^{2}\right)
$$

Công thức tính lưu lượng dòng chảy qua đỉnh đập:

$$
\mathrm{Q}=\mathrm{k}_{\mathrm{s}} \mathrm{b}_{\mathrm{c}} \sqrt{g\left(h-h_{b}\right)}\left(h-h_{c}\right)
$$

Trong đó: $b$ là chiều rộng đáy; $g$ là gia tốc trọng trường; $h$ là mực nước hồ chứa; $h_{b}$ là cao trình đáy vết vỡ.

$\mathrm{C}_{\text {weir }}=0,54643$ : hệ số đập cho phần nằm ngang

$\mathrm{C}_{\text {slope }}=0,431856$ : hệ số độ dốc đập

$\mathrm{S}$ : độ dốc thành bên của vết vỡ

$\mathrm{C}_{\mathrm{v}}$ : hệ số tổn thất 
$\mathrm{k}_{\mathrm{s}}$ : hệ số điều chỉnh do ngập nước

$h_{c}$ : cao trình đỉnh

$$
C_{\text {weir }} \sqrt{g}=0.5 \sqrt{9.81}=1.711\left(\frac{m^{\frac{1}{2}}}{s}\right)=3.1\left(\frac{f t^{\frac{1}{2}}}{s}\right)
$$

$b_{c}$ : chiều dài đỉnh còn lại (vuông góc với dòng chảy)

$$
c_{v}=1+\frac{c_{B} Q^{2}}{g W_{R}^{2}\left(h-h_{b, t e r m}\right)^{2}\left(h-h_{b}\right)}
$$

Hệ số tổn thất $\mathrm{C}_{\mathrm{v}}$ được xác định theo công thức:

$$
k_{s}=\max \left(1-27.8\left(\frac{\left(h_{d s}-h_{b}\right)}{\left(h-h_{b}\right)}-0.67\right)^{3}, 0\right)
$$

Hệ số điều chỉnh do ngập:

Trong đó: $\mathrm{C}_{\mathrm{B}}$ là hệ số Barter $(0,740256) ; \mathrm{W}_{\mathrm{R}}$

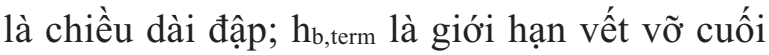
cùng; $h_{\text {ds }}$ là mực nước hạ lưu.

Các thông số ban đầu:

+ Cao trình vỡ ban đầu: $Z_{d}=91,93 m$

+ Cao trình vỡ cuối cùng: $Z_{\mathrm{c}}=65,00 \mathrm{~m}$

+ Bề rộng vết vỡ ban đầu: $\mathrm{B}_{\mathrm{d}}=1,0 \mathrm{~m}$

+ Bề rộng vỡ cuối cùng: $\mathrm{B}_{\mathrm{c}}=380,0 \mathrm{~m}$

Kết quả tính toán được quá trình lưu lượng về hạ du đập Định Bình; trong đó quá trình xả lũ với thời đoạn 1 giờ, quá trình vỡ được với thời đoạn 5 phút. Lưu lượng ứng với tình huống vỡ đập của lũ thiết kế và kiểm tra được biên tập với định dạng của mô hình Mike để mô phỏng ngập lụt cho các tình huống vỡ đập.

\section{Số liệu các biên mô hình}

Tần suất lưu lượng, mực nước triều lớn nhất năm được tính toán từ giá trị lớn nhất năm bằng phương pháp Pearson III. Quá trình lưu lượng lũ ứng với các tần suất tại biên gồm hồ Định Bình, cầu Phú Phong và Diêu Trì được thu phóng từ đường quá trình lũ điển hình bằng phương pháp thu phóng đồng dạng cùng hệ số. Tại hồ Định Bình, đường quá trình lưu lượng ứng với tần suất $1 \%$ và $3 \%$ được thu phóng từtrận lũ lịch sử năm 1987 (Hình 7), tần suất $5 \%$ và $10 \%$ thu phóng từ trận lũ lớn nhất năm 1980 (Hình 8). Tại trạm Diêu trì, tần suất $1 \%$ và $3 \%$ được thu phóng từ trận lũ lịch sử năm 2009 (Hình 9), tần suất 5\% thu phóng từ trận lũ lớn nhất năm 2013, tần suất 10\% thu phóng từ trận lũ lớn nhất năm 1998 [3].

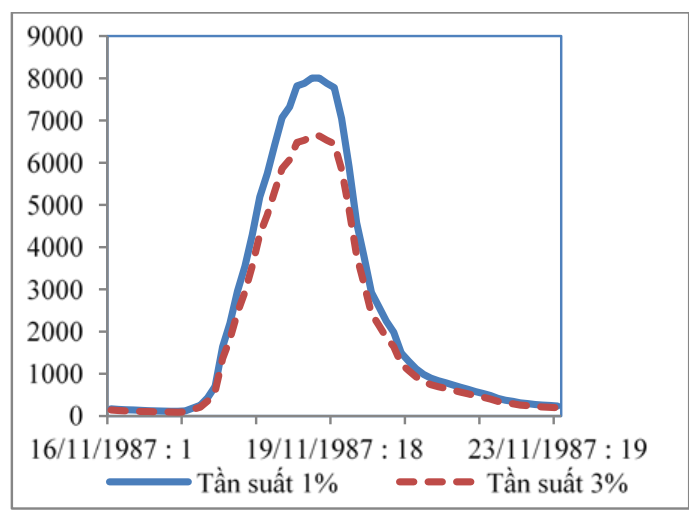

Hình 7. Thu phóng đường quá trình lũ tại Định Bình tần suất $1 \%$ và $3 \%$

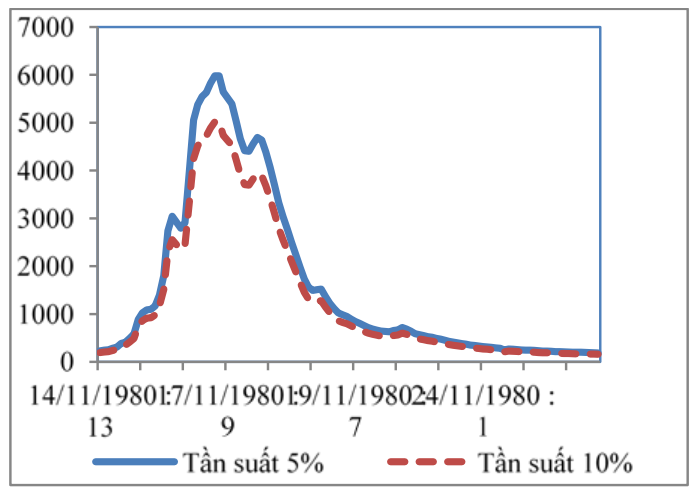

Hình 8. Thu phóng đường quá trình lũ tại Định Bình tần suất $5 \%$ và $10 \%$

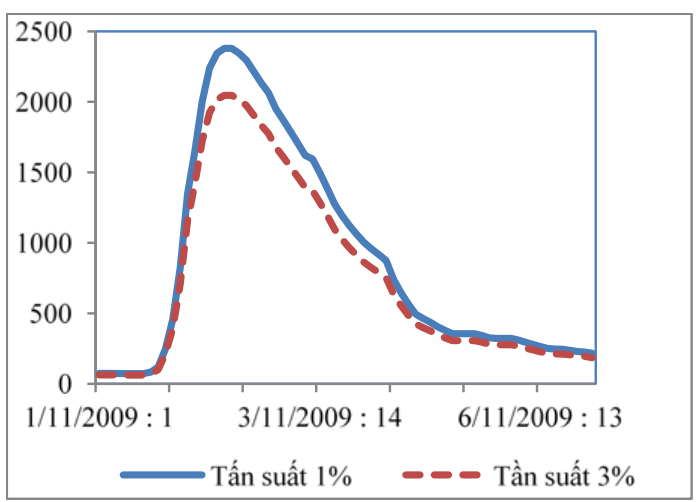

Hình 9. Biểu đồ thu phóng đurơng quá trình lũ tại trạm Diêu Trì

Từ mô đun sóng vỡ đập đã tính toán được quá trình lưu lượng về hạ du đập ứng với lũ thiết kế với lưu lượng đỉnh lũ về hồ đạt $8,130 \mathrm{~m}^{3} / \mathrm{s}$ và lũ kiểm tra với lưu lượng đỉnh lũ về hồ đạt $9,690 \mathrm{~m}^{3} / \mathrm{s}$ (Hình 10). Lưu lượng lớn nhất về hạ du khi vỡ đập ứng với lũ thiết kế đạt $32,520 \mathrm{~m}^{3} / \mathrm{s}$ 
và lũ kiểm tra đạt $38,760 \mathrm{~m}^{3} / \mathrm{s}$ [3].

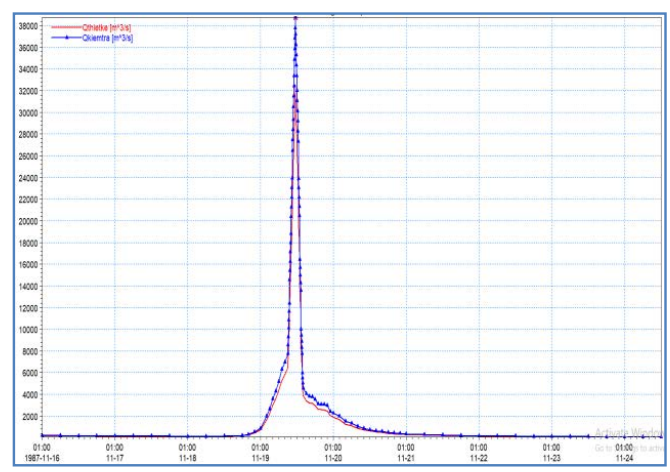

Hình 10. Đưòng quá trình lưu lự̛ng võ đập Định Bình

Sông Kôn - Hà Thanh đổ ra đầm Thị Nại trước khi nhập vào biển tại cửa Quy Nhơn, mực nước triều tại các cửa ra được tính toán từ trạm hải văn Quy Nhơn. Quá trình mực nước triều ứng với các tần suất được thu phóng từ con triều cường lớn nhất năm 2006 bằng phương pháp thu phóng đồng dạng cùng hệ số (Hình 11).Biên triều mô phỏng cho kịch bản vỡ đập Định Bình ứng với lũ thiết kế là $0,1 \%$, kiểm tra là $0,02 \%$ [3].

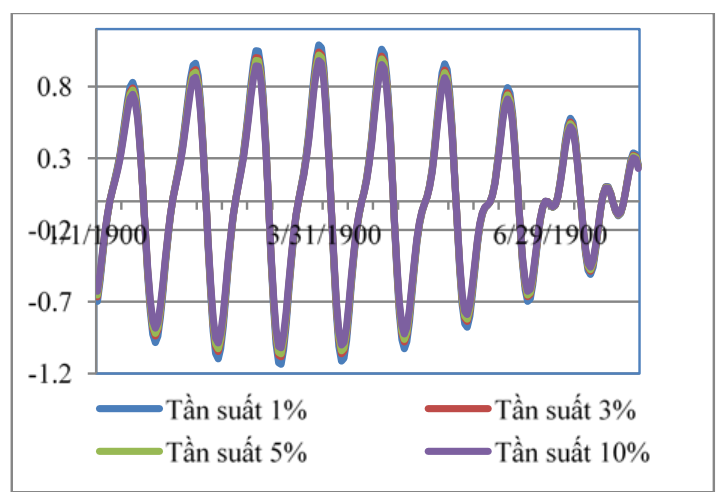

Hình 11. Biểu đồ thu phóng mua mục nước triều tại Quy Nhơn

Lượng mưa gia nhập khu giữa là lượng mưa 5 ngày lớn nhất tại trạm Phù Cát, An Nhơn, Bình Tường và Quy Nhơn. Trận mưa điển hình là số liệu mưa 5 ngày lớn nhất năm 1987 , được sử dụng để thu phóng cùng hệ số thu được lượng mưa thời đoạn 1 giờ ứng với tần suất $1 \%, 3 \%$, $5 \%$ và $10 \%$ (Hình 12$)$ [3].

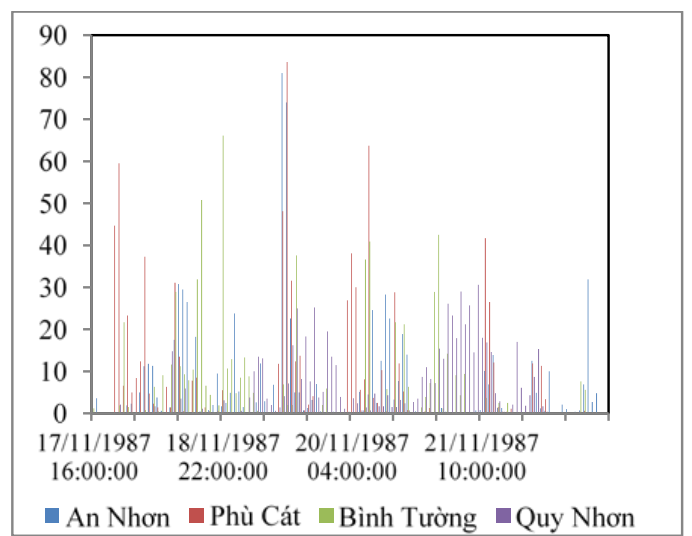

Hình 12. Biểu đồ thu phóng mura trận 5 ngày lớn nhất tần suất $1 \%$

\section{Kết quả và thảo luận}

Từ bản đồ ngập lụt và xác định vùng ngập trên phần mềm MapInfo cho thấy: với kịch bản xả lũ khẩn cấp $1 \%, 3 \%$ và $5 \%$ xảy ra trên lưu vực sông Kôn - Hà Thanh có thể thấy mức ngập phổ biến là trong khoảng 4 - $6 \mathrm{~m}$ với tổng diện ngập chiếm trên $40 \%$ và $50 / 53$ xã bị ảnh hưởng; với kịch bản $10 \%$ diện tích ngập phổ biến là $2-4 \mathrm{~m}$ chiếm trên $40 \%$ và $51 / 53$ xã bị ảnh hưởng ngập. Diện tích ngập phổ biến từ $2-4 \mathrm{~m}$ và $4-6 \mathrm{~m}$ tập trung ở kịch bản $5 \%$ và $10 \%$ chiếm $70 \%$ diện tích ngập; diện tích ngập phổ biến tư $4-6 \mathrm{~m}$ và từ $6-8 \mathrm{~m}$ tập trung ở kịch bản $1 \%$ và $3 \%$ chiếm trên $60 \%$ diện tích ngập. Diện tích ngập trên $8 \mathrm{~m}$ rất ít chủ yếu tập trung ở trong lòng sông và các vùng trũng. Kịch bản vỡ đập, độ sâu ngập phổ biến từ $5-8 \mathrm{~m}$, với tổng diện tích ngập từ 45 $50 \%$ và có $50 / 53$ xã bị ảnh hưởng. Độ sâu ngập lụt ứng với kịch bản vỡ đập lũ thiết kế cao hơn kịch bản xả lũ khẩn cấp $1 \%$ khoảng $15 \%$ và kịch bản vỡ đập với lũ kiểm tra cao hơn khoảng 20\%. Kịch bản vỡ đập tăng diện tích vùng ngập khoảng $5 \%$ so với kịch bản xả lũ khẩn cấp tấn suất $1 \%$ [3].

Vận tốc dòng chảy trong vùng ngập ứng với kịch bản xả lũ khẩn cấp tần suất $1 \%, 3 \%, 5 \%$ phổ biến từ 0,5 đến $1,2 \mathrm{~m} / \mathrm{s}$ trong vùng độ sâu ngập từ $4-6 \mathrm{~m}$; tần suất $10 \%$ phổ biến từ 0,3 đến $1,0 \mathrm{~m}$ trong vùng độ sâu ngập $2-4 \mathrm{~m}$. Trường hợp vỡ đập, vận tốc dòng chảy trong vùng ngập tăng mạnh và phổ biến từ $1-2 \mathrm{~m} / \mathrm{s}$ trong vùng có độ sâu ngập $5-8 \mathrm{~m}$. Thời gian duy trì ngập ứng với tần suất $1 \%, 3 \%, 5 \%$ phổ biến từ $48-72$ giờ; tần 


\section{BÀI BÁO KHOA HỌC}

suất $10 \%$ từ 36 - 60 giờ; vỡ đập từ 30 - 40 giờ [3]. Bản đồ ngập lụt hạ lưu sông Kôn - Hà Thanh khi xả lũ khẩn cấp và vỡ đập được thể hiện từ hình 13 đến 18 dưới đây.

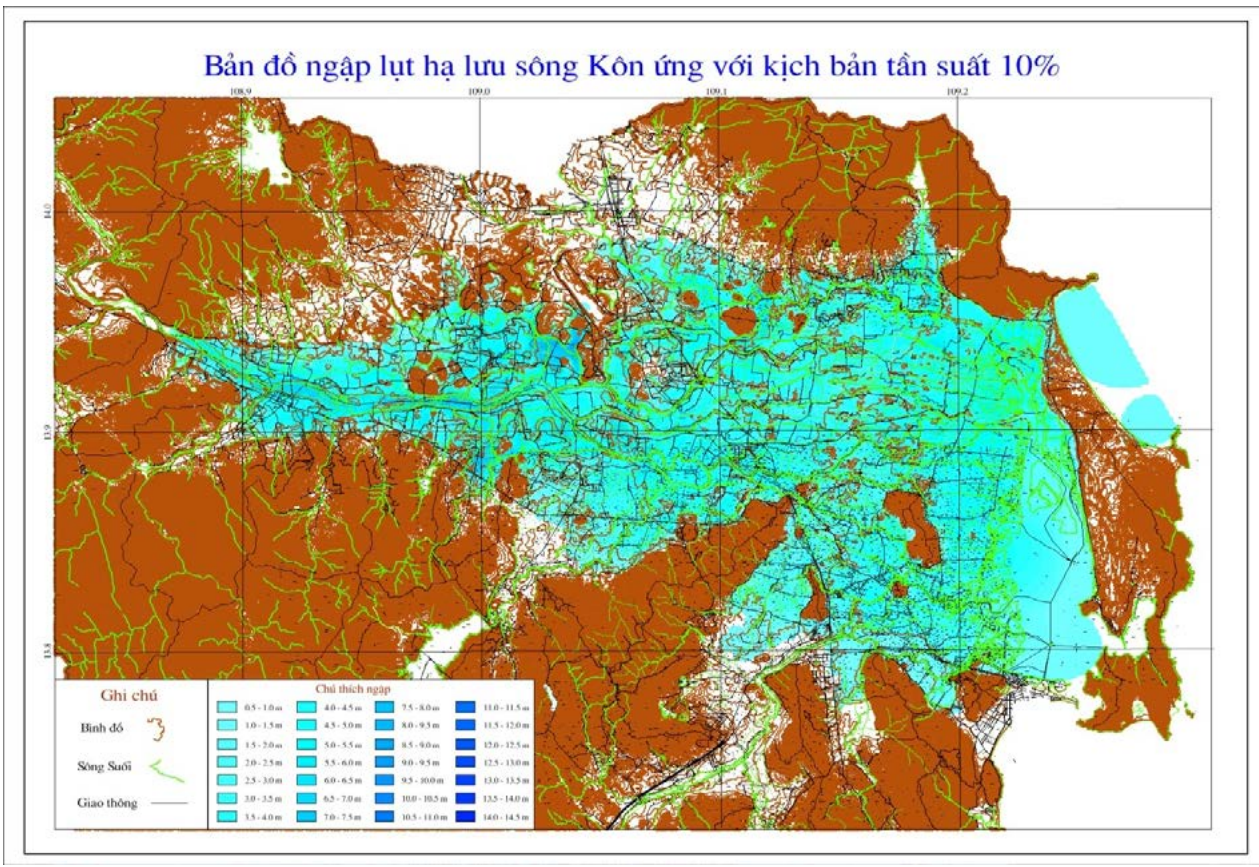

Hình 13. Bản đồ ngập lụt xả lũ khẩn cấp tần suất 10\% [3]

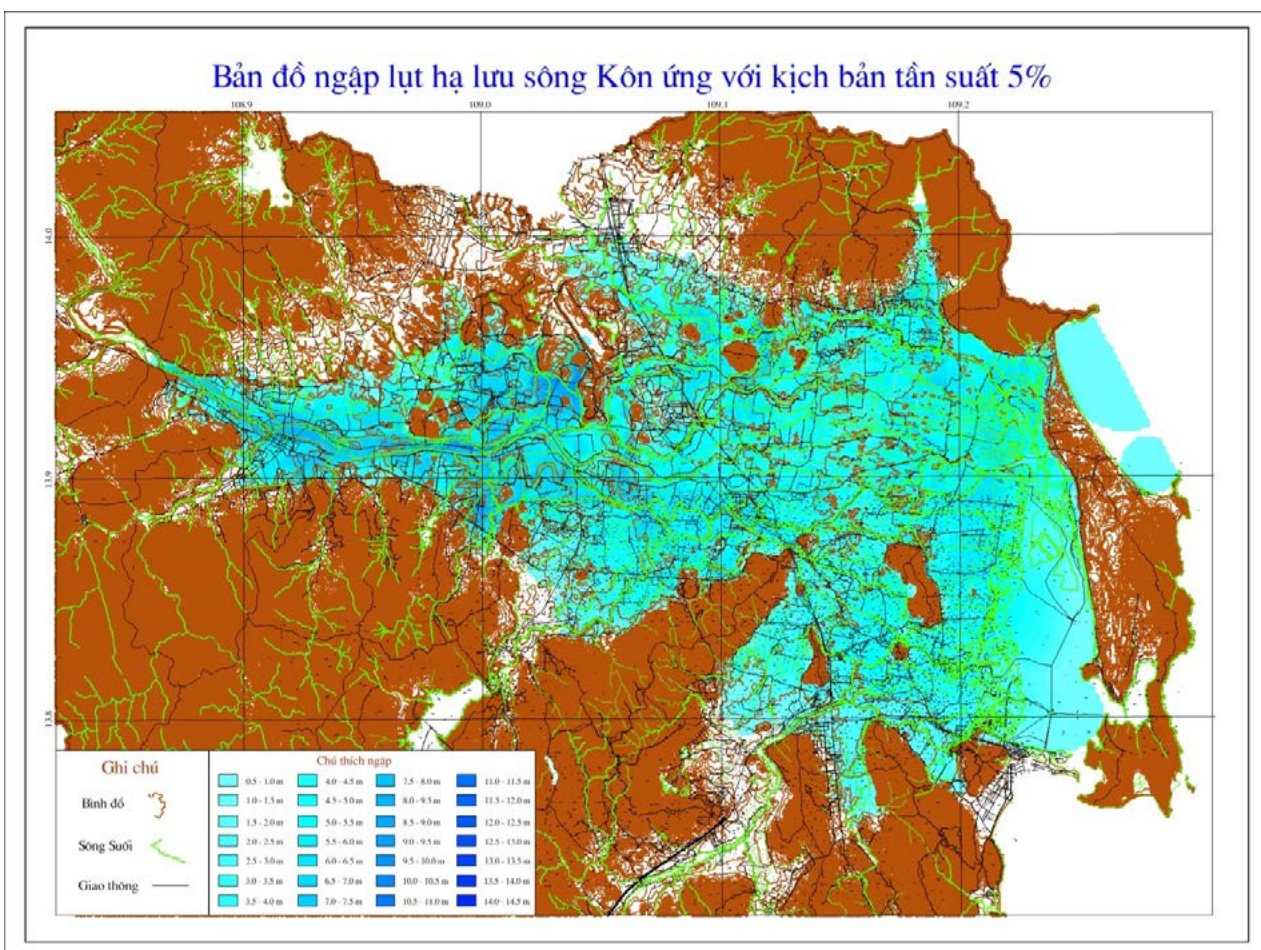

Hình 14. Bản đồ ngập lụt xả lũ khẩn cấp tần suất 5\% [3] 


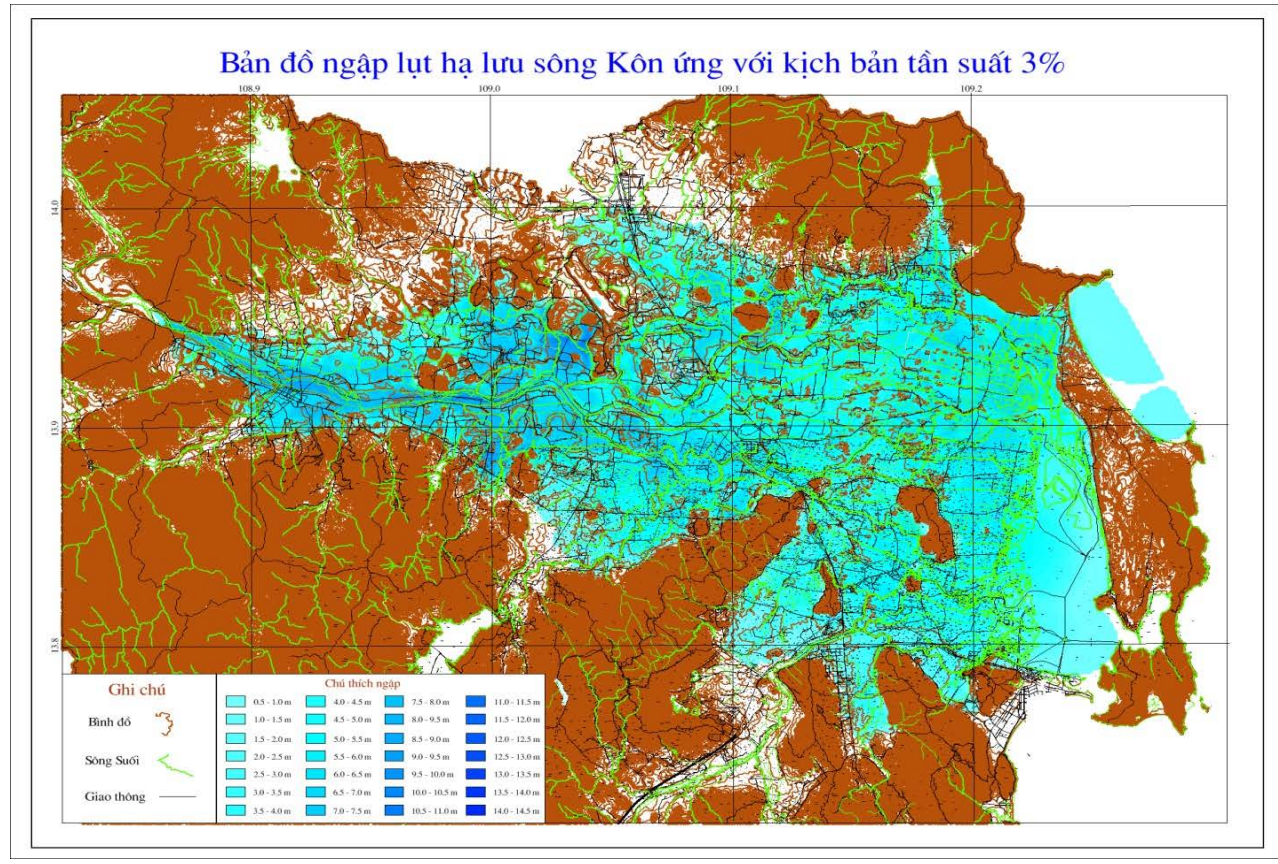

Hình 15. Bản đồ ngập lut xả lũ khẩn cấp tần suất 3\% [3]

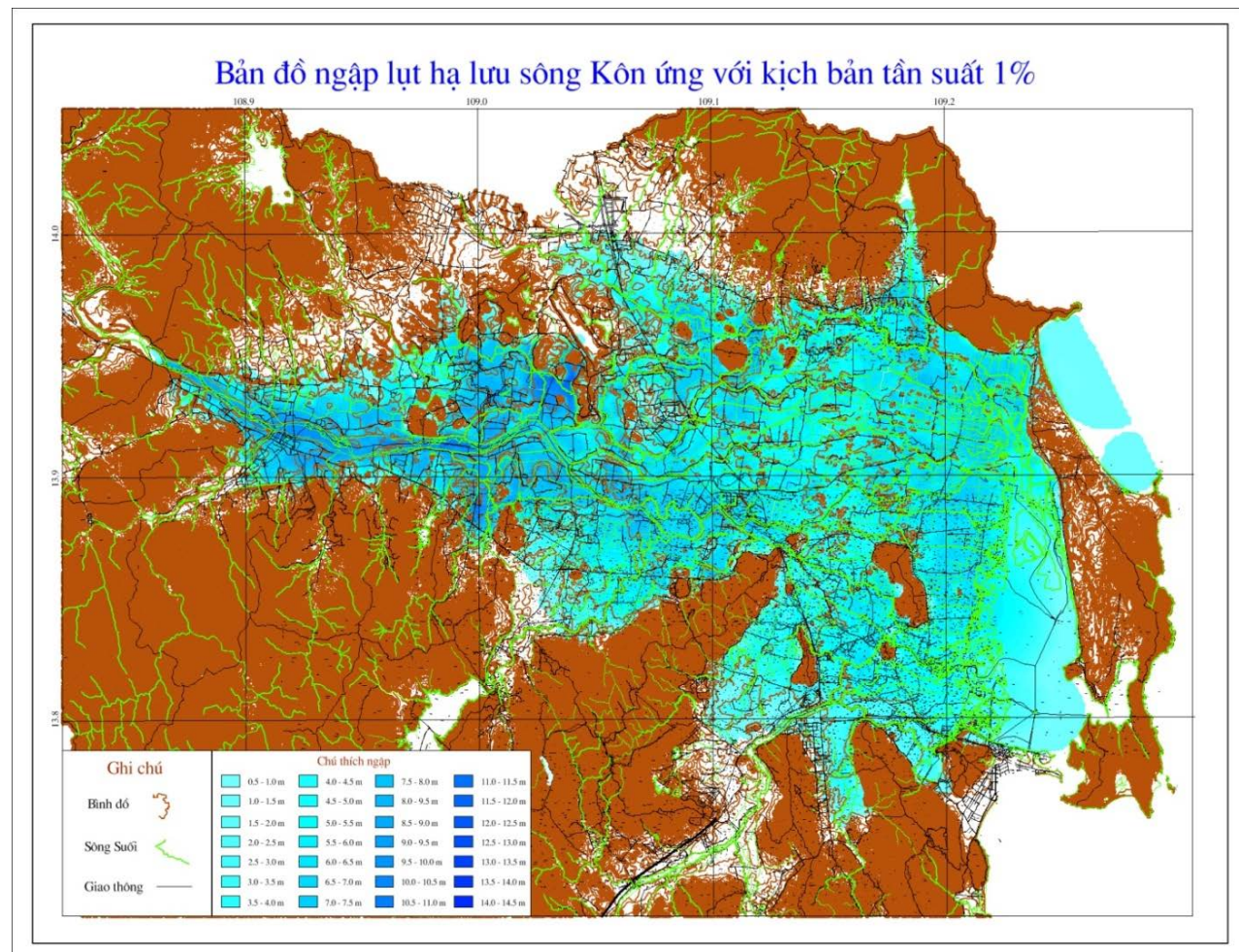

Hình 16. Bản đồ ngập lut xả lũ khẩn cấp tần suất 1\% [3] 


\section{BÀI BÁO KHOA HỌC}

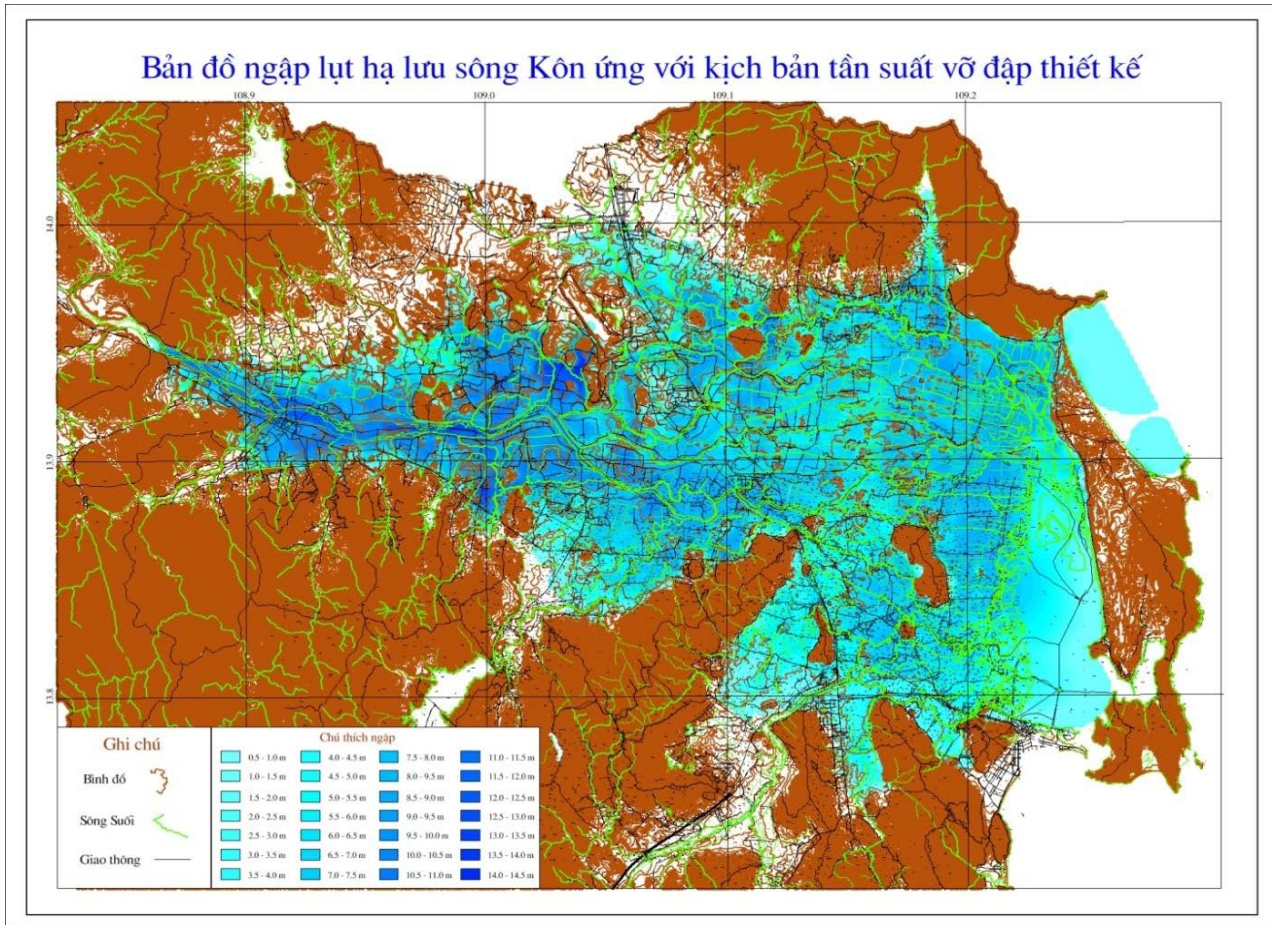

Hình 17. Bản đồ ngập lụt vỡ đập úng với lũ thiết kế [3]

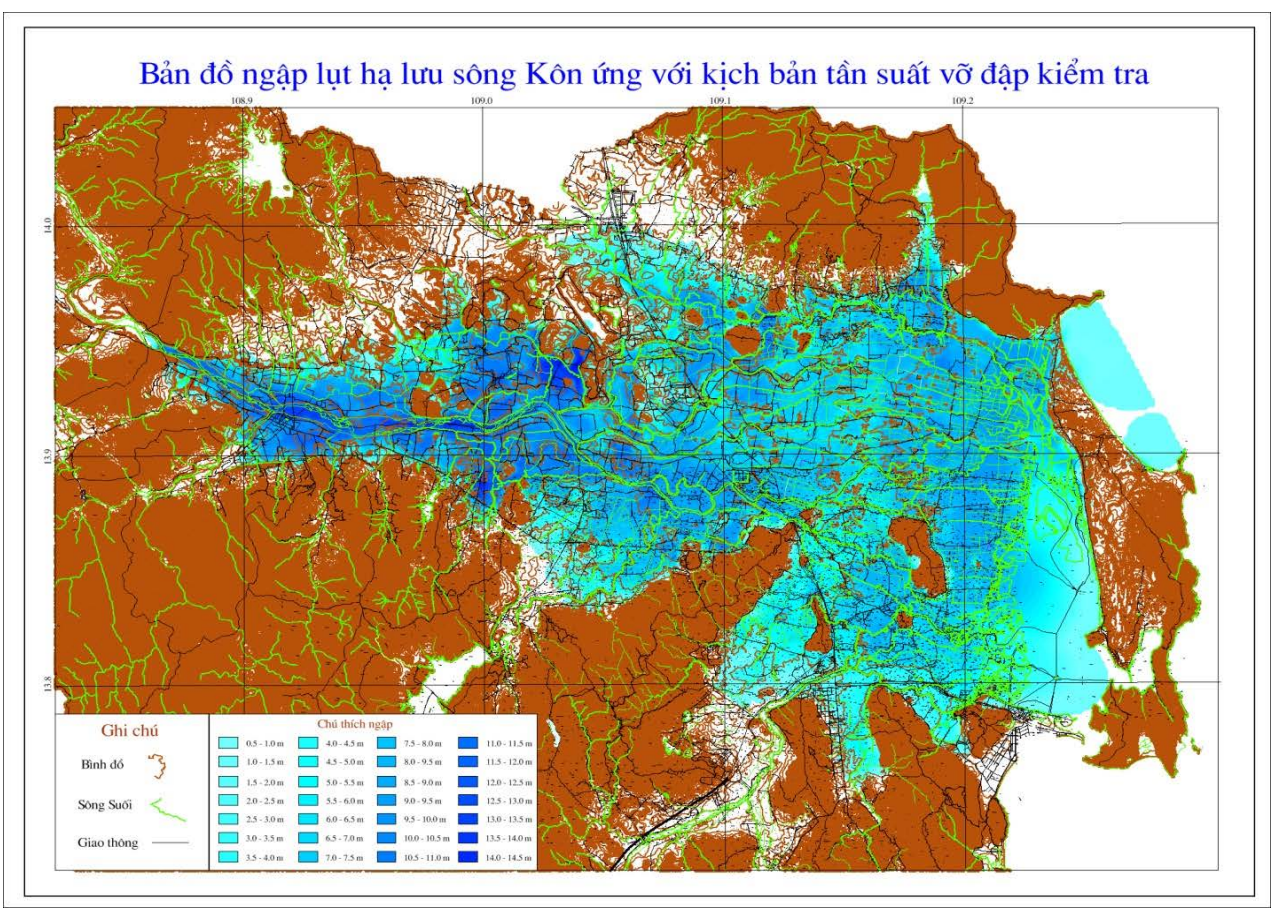

Hình 18. Bản đồ ngập lụt vỡ đập úng với lũ kiểm tra [3]

\section{Kết luận}

- Bộ thông số mô hình Mike Flood đủ tin cậy để mô phỏng ngập lụt ứng với các trường hợp xả lũ, vỡ đập và lũ tự nhiên vùng hạ lưu sông Kôn - Hà Thanh.

- Ngập lụt ứng với trường hợp vỡ đập có độ sâu ngập và vận tốc dòng chảy lớn hơn nhưng thời gian duy trì ngắn hơn so với trường hợp xả lũ cùng tần suất.

- Độ dốc mặt nước trong trường hợp vỡ đập lớn hơn nhiều so với trường hợp xả lũ cùng tần suất nên quá trình lan truyền ngập lụt do vỡ đập 
tạo thành dạng sóng ở vùng hạ du đập.

- Lập bản đồ ngập lụt trong trường hợp võ đập là rất cần thiết, đặc biệt là trong bối cảnh có nhiều hồ bị vỡ. Từ đó xây dựng được bản đồ hiểm họa không chỉ do thiên tai mà còn do tác động của con người.
- Úng dụng mô hình thủy lực hai chiều để mô phỏng ngập lụt giúp chi tiết theo không gian và thời gian, xây dựng được nhiều thành phần trong bản đồ ngập. Kết quả là cơ sở để chi tiết cấp độ rủi ro do ngập lụt có độ tin cậy cao.

Lời cảm ơn: Nhóm nghiên cúu xin chân thành cảm ơn sụ hỗ trợ của đề tài "Nghiên cúu co" sở khoa họ và thực tiê̂n phục vu cảnh báo cấp độ rủi ro thiên tai do lũ và ngập lụt cho các địa phương thuộc khu vưc Nam Trung Bộ. Áp dụng thí điểm cho lưu vực sông Kôn-Hà Thanh" mã số TNMT.2017.05.08 trong việc thực hiện và công bố nghiên cứu này.

\title{
Tài liệu tham khảo
}

1. Nguyễn Văn Lý (2009), Báo cáo tổng kết đề tài: Xây dựng bản đồ nguy co ngập lụt tỉnh Bình Định, Co quan chủ trì: Đài Khí tương Thủy văn khu vục Nam Trung Bộ, Cơ quan chủ quản: Sở Khoa học và Công nghệ tỉnh Bình Định.

2. Đặng Thanh Mai (2016), Báo cáo tổng kết đề tài: Nghiên cứu xây dụng công nghệ dụ báo lũ và cảnh báo ngập lụt cho các sông chính tỉnh Bình Định và Khánh Hòa, Cơ quan chủ trì: Trung tâm Dự báo Khí tượng Thủy văn Trung ương, Cơ quan chủ quản: Bộ Tài nguyên và Môi trường.

3. Nguyễn Văn Lý (2019), Báo cáo tổng kết đề tài: Nghiên cứu cơ sỏ̉ khoa học và thực tiễn phucc vu cảnh báo cấp độ rủi ro thiên tai do lũ và ngập lụt cho các địa phương thuộc khu vực Nam Trung Bộ; Ap dụng thi điểm cho lưu vực sông Kôn - Hà Thanh, Cơ quan chủ trì: Đài Khí tượng Thủy văn khu vực Nam Trung Bộ, Cơ quan chủ quản: Bộ Tài nguyên và Môi trường.

4. DHI (2014), Mike 11 User Guide.

5. DHI (2014), Mike 21 Hydrodynamic Module, Step - by - step training guide.

6. DHI (2014), Mike Flood User Manual.

7. DHI (2014), Mike Toolbox User Manual.

\section{APLYING MIKE MODEL FOR INUNDATION SIMUATION IN DISCHARGING FLOODING AND BREAKING DINH BINH DAM} Bui Van Chanh', Nguyen Van Ly ${ }^{1}$

${ }^{1}$ Southern Central Region HydroMeteorology Center, NHMS

\begin{abstract}
Dinh Binh reservoir is the most largest reservoir in Binh Dinh, operating the inundation downstream of Kone - Ha Thanh basin. In recent years, there have been increasing numbers of hight flooding in Kone - Ha Thanh. The time of inundations prolongs so the operation of Dinh Binh reservoir to ensure the dam safety and reduce flooding in downstream that is necessary. During hight flood come to Dinh Binh reservoir, safety operation to reduce inundation is difficult because the reservoir is flood volume and often must emergency flooding discharging. If the revervoir is done that, inundation will be deeper; special, flood by dam breaking is not only deeper but it also has higher velocity. As a result, researching for establish inundation map by dam breaking scripts and emergency flooding discharging to inundation and risk warning to reduce damage by wrong operating revervoir include Dinh Binh reservoir which is necessary.
\end{abstract}

Keywords: Inundation, Kone - Ha Thanh basin, Dinh Binh reservoir. 